ARTICLE

\title{
Situation of study (SoS) on health education implemented in a co-creation (CoC) process
}

\author{
Graça Simões de Carvalho' (D) \\ Eva Teresinha de Oliveira Boff" iD \\ Maria Cristina Pansera de Araújo" (D)
}

\begin{abstract}
Situation of study (SoS) has been reported as an excellent strategy to promote students' significant learning. This work intended to demonstrate how a SoS on health education ("Knowing cancer: a way to life") can be implemented within the co-creation $(\mathrm{CoC})$ framework. The study was carried out in a middle school, with the participation of five groups: students (14-15 years old), teachers, future teachers, university teacher trainers and health professionals. The 10 activities were carried out in school and outdoors for five months, undergoing a process of self-reflexive cycle: "reflecting and planning", "acting and observing", and "analyzing and reflecting". Transcripts of debates and of students' and teachers' texts were subject to content analysis. This study on a topic of health education demonstrated that the Situation of Study implemented in a co-creation process was very efficient for students to develop significant learning.
\end{abstract}

\section{KEYWORDS}

situation of study; educational co-creation; health education; reflexive cycles; action research.

'Centro de Investigação em Estudos da Criança, Instituto de Educação, Universidade do Minho, Braga, Portugal.

"Universidade Regional do Noroeste do Estado do Rio Grande do Sul, ljuí, RS, Brazil. 


\section{SITUAÇÃO DE ESTUDO (SdE) EM EDUCAÇÃO PARA A SAÚDE IMPLEMENTADA EM PROCESSO DE COCRIAÇÃO (COC)}

\section{RESUMO}

A situação de estudo (SoS) tem revelado ser uma estratégia eficiente para promoção de aprendizagens significativas. Este estudo teve como objetivo demonstrar como uma $\mathrm{SdE}$ sobre educação em saúde ("Conhecendo o câncer: um caminho para a vida”) pode ser implementada no âmbito do processo de cocriação $(\mathrm{CoC})$. O estudo foi realizado numa escola de ensino médio, com a participação de cinco grupos: alunos (14-15 anos), professores, futuros professores, formadores universitários de professores e profissionais de saúde. As dez atividades foram realizadas na escola e no exterior em cinco meses, desenvolvendo um processo de ciclo autorreflexivo: "refletir e planejar", "atuar e observar" e "analisar e refletir". As transcrições dos debates e dos textos dos alunos e professores foram submetidas a análise de conteúdo. Este estudo demonstrou que a Situação de Estudo implementada em um processo de cocriação foi muito eficiente para os alunos desenvolverem um aprendizado significativo.

\section{PALAVRAS-CHAVE}

situação de estudo; cocriação educacional; educação em saúde; ciclos reflexivos; pesquisa-ação.

\section{SITUACIÓN DE ESTUDIO (SdE) EN EDUCACIÓN PARA LA SALUD IMPLEMENTADA EN EL PROCESO DE CO-CREACIÓN (COC)}

\section{RESUMEN}

La situación de estudio ( $\mathrm{SdE}$ ) es una excelente estrategia para la promoción de aprendizajes significativos. El objetivo de este trabajo es demostrar cómo una $\mathrm{SdE}$ sobre educación en salud ("Conociendo el cáncer: un camino para la vida”) puede ser implementada en el ámbito del proceso de co-creación (CoC). El estudio fue realizado en una escuela de educación secundaria, con la participación de 5 grupos: estudiantes (14-15 años), profesores, futuros profesores, formadores universitarios de profesores y profesionales de salud. Las diez actividades fueron realizadas en la escuela y en el exterior durante cinco meses, desarrollando un proceso de ciclo autorreflexivo "reflexionar y planear", "actuar y observar" y "analizar y reflexionar". Las transcripciones de los debates y los textos de estudiantes y profesores fueron sometidos a análisis de contenido. Este estudio demostró que la situación de estudio fue muy eficiente para que los estudiantes desarrollen aprendizajes significativos.

\section{PALABRAS CLAVE}

situación de estudio; co-creación educacional; educación en salud; ciclos de reflexión; investigación activa. 


\section{INTRODUCTION}

The Situation of Study (SoS) is a process of building conceptual significance through learning science by questioning and searching about a topic of social relevance identified by students' experiences in their real world and is conceived, planned, implemented, and analyzed through participants' mediation to make the concepts of science meaningful (Boff, Rosin and Pinto, 2012; Santos, 2007). This type of participatory action is viewed as an intervention in social reality (Miranda and Resende, 2006). In general, the SoS process is carried out in four interconnected stages:

- Identifying a real, socio-environmental, complex situation: students and teachers discuss and define which specific issues deserve to be addressed;

- Planning the SoS: elaborating of activities and learning tools by the teachers and other specialized professionals or practitioners in the situation to be studied. This group seeks to understand the situation and identify the curriculum topics that can be linked to the SoS. It contributes to the transposition of the envisaged formal curriculum to the actual classroom curriculum;

- Implementing the SoS: school classroom activities are carried out weekly or once every two weeks during at least a 3-month term. Such activities are followed by assessment meetings including students, teachers, and other professionals involved in the $\mathrm{SoS}$ to analyze the process carried out, identify the needs for progressing and (re-)planning the SoS, and thus create reflexive spirals, as initially proposed by Carr and Kemmis (1988) in action research activities;

- Analyzing and reflecting: after implementing the specific SoS, a final global evaluation of the process is carried out with students and teachers to propose and plan a subsequent $\mathrm{SoS}$.

The SoS process develops within a co-creation framework, in the sense that students are active participants engaged in interactive relationships with teachers and other professionals to get what they want to learn. The term co-creation $(\mathrm{CoC})$ has its origins in service marketing and business management (Prahalad and Ramaswamy, 2000, 2004). It refers to a more participative process in which customers are considered not only consumers but also actively engaged in interactive relationships with brands and businesses to create on-demand and made-to-order products. Thus, that value creation is no longer a process taking place during manufacturing, but an activity that customers govern in their consumption context (Alves, Fernandes and Raposo, 2016; Bharti, Agrawal and Sharma, 2015). The dialogue between the customer and the organization generates an interactive relationship that is the opportunity to stimulate the exchange of knowledge in order to solve issues of mutual interest to meet needs and expectations (Pinar et al., 2011; Ribeiro, Tavares and Costa, 2016). This concept of $\mathrm{CoC}$ of value has been a matter of recent literature reviews in the business field (Alves, Fernandes and Raposo, 2016; Bharti, Agrawal and Sharma, 2015; Campos et al., 2018; Kohler et al., 2011; Ramírez and 
García-Peñalvo, 2018; Ribeiro, Tavares and Costa, 2016; Roberts and Darler, 2017; Voorberg, Bekkers and Tummers, 2015).

This classical business concept of the value of $\mathrm{CoC}$ has been recently introduced and adapted to the education (Dean, Griffin and Kulczynski, 2016; Pinar et al., 2011; Ribes-Giner, Perello-Marín and Díaz, 2016; Voorberg, Bekkers and Tummers, 2015) and health sectors (Boer, Nieboer and Cramm, 2017; Dean, Griffin and Kulczynski, 2016; Greenhalgh et al., 2016; Pinar et al., 2011; Ramírez and García-Peñalvo, 2018; Ribes-Giner, Perello-Marín and Díaz, 2016; Voorberg, Bekkers and Tummers, 2015; WHO, 2013). In both situations, students (Pinar et al., 2011) and patients/clients (Boer, Nieboer and Cramm, 2017; Greenhalgh et al., 2016) are seen as customers in the CoC process. This view goes beyond the student-centered teaching and learning process (Ribes-Giner, Perello-Marín and Díaz, 2016) or client-centered care (Boer, Nieboer and Cramm, 2017) as students or patients/clients are active participants from the very beginning of the $\mathrm{CoC}$ process of learning or care, respectively.

Several studies have been looking at $\mathrm{CoC}$ approaches in higher education (Dean, Griffin and Kulczynski, 2016; Pinar et al., 2011; Ribes-Giner, Perello-Marín and Díaz, 2016). Here, students can be seen as customers in two ways, as the target public for recruitment (Pinar et al., 2011) or as active agents of their learning (Dean, Griffin and Kulczynski, 2016; Ribes-Giner, Perello-Marín and Díaz, 2016). The first perspective is related to the financial difficulties of higher education institutions competing for the same students and developing marketing services to attract students (Vesna and Nemanja, 2016). Institutions struggle to understand and embrace students' demands; therefore, some institutions have implemented processes of $\mathrm{CoC}$ where students or student associations play the role of customers in interacting actively with the institution staff for the production of communication media to attract prospective students (Pinar et al., 2011).

The second perspective, which is more relevant to the present study, looks at students as customers in the $\mathrm{CoC}$ process of teaching and learning. Moving from the traditional teacher-centered teaching approach to the student-centered learning approach has been a matter of intense research with many pedagogical variations as described, for example, by Crumly et al. (2014). In the CoC process, students have a central role in the teaching-learning process, in a "new innovative approach, which helps modify the current procedures and also provides students of better opportunities on the labor market powers"(Velasco, 2014 apud Ribes-Giner, Perello-Marín and Díaz, 2016, p. 73). The main novelty that CoC brings is that students (as customers) become active agents with an important role right from the initial phase of the development process (Witell et al.,2011). Dean, Griffin and Kulczynski (2016) consider two important areas of students' active participation in the $\mathrm{CoC}$ process: engagement in learning and student connectedness. Student engagement in learning "is defined as the extent of involvement in a range of educationally purposeful in-class and out-of-class activities" (Dean, Griffin and Kulczynski, 2016, p. 327), with students interacting with teachers from the very beginning of the co-creation process (Witell et al., 2011). Student connectedness "is defined as the extent to which students interact and develop relationships with others (peers, 
faculty members, and administrators) and thereby demonstrate positive feelings of association and belonging" (Dean, Griffin and Kulczynski, 2016, p. 327).

Nowadays the school role is to contribute to children's and adolescents' holistic development (Canoy et al., 2007; Carvalho and Berger, 2012; Gordon et al., 2011; Ismail, Badayai and Kulasingam, 2017; Marmott, 2010), not only to be a space for the transmission of curriculum contents that may not be linked to pupils' reality (Oppermann et al., 2018), ethnical condition (Donovan, 2017) or the age of development (Baram-Tsabari and Yarden, 2009). In-school and outdoor activities should address pupils' daily practices so that new knowledge can promote not only pupils' healthy life (Martin et al., 2016) but also provide adequate social life conditions for pupils to understand and develop full awareness of their context, their responsibilities and their rights as they learn the curriculum contents (Brasil, 1998; Kilgour et al., 2015; Pommier et al., 2010). In addition, some studies (Busch, De Leeuw and Schrijvers, 2012; Centeio et al., 2018; Flay, 2002; Morés and Silveira, 2013) emphasized the importance of implementing comprehensive health activities in real-world contexts to achieve the needed meaningful progress in health promotion. Such activities, when associated with school-based curricula, may influence better changes in adolescents' behavior (Flay, 2000). Furthermore, health education and health promotion must take into consideration how teachers perceive their mission and understand pupils' holistic development (Jourdan, 2011; Jourdan et al., 2008; Leite et al., 2015).

Since education systems vary from country to country, health education can be seen either as a subject on its own, being a specific component of the curriculum, or as a transversal theme embedded within all curriculum subjects (Hubley, Copeman and Woodall, 2013). In the case of Brazil, the document on the national curricular parameters for the natural sciences of basic education refers to health as being a transversal issue, related to several natural sciences themes, and also addressing, as far as possible, economic, political, social, and historical factors (Brasil, 1997, 1998).

National curricular parameters emphasize the issue of meaningful learning by saying that "contents must be developed in topics of meaningful work for students, such as searching on the ways of combating dengue, while the presentation of such topics out of context is of little value" (Brasil, 1998, p. 46). This is highly relevant for the "articulation of the teaching-learning process" (Thiesen, 2008, p. 597).

Therefore, in the field of health education and health promotion, schools must develop actions linked to the school curricular contents, through a multidisciplinary activity. The present study analyzes the implementation of the SoS on the topic "Knowing cancer: a way to life", which was developed within the perspective of $\mathrm{CoC}$ process.

\section{METHODOLOGY}

The topic "Knowing cancer: a way to life" was developed in the context of a SoS where conceptual meaning was built through learning science by doing research (Boff and Del Pino, 2018) in the process of CoC (Dean, Griffin and Kulczynski, 
2016; Ribes-Giner, Perello-Marín and Díaz,2016). This was a collaborative research process involving a Brazilian public middle school, a university research center and the community, which lasted for five months. The educational methodology used is included in the general theoretical framework of collaborative research, participatory action research, and critical pedagogy, as discussed by Miskovic and Hoop (2006).

\section{PARTICIPANTS}

Five groups of participants were involved in this study. The groups were named as follows: $\mathrm{S}$ for Students; $\mathrm{T}$ for Teachers; $\mathrm{F}$ for Future teachers; $\mathrm{U}$ for University teacher trainers; and $\mathrm{H}$ for Health professionals. They had this configuration:

- S: Students of middle school: 32 students of grade 10 (14-15 years old);

- T:Teachers of grade-10 middle school: seven teachers of Natural Sciences (Biology, Chemistry, and Physics), Geography, History, Mathematics, and Portuguese Language;

- F: Future teachers: five Natural Sciences (Biology, Chemistry, and Physics) university students;

- U: University teacher trainers: three lecturers of Natural Sciences (Biology, Chemistry, and Physics);

- H: Health professionals: three doctors, two nurses, one nutritionist, one psychologist, and one physiotherapist.

In group $\mathrm{S}$, half of the students were boys and half girls, while in all other groups the participants were women, except for the three doctors who were men.

To preserve anonymity, participants were addressed fictitious names. The first letter of each fictitious name matched the group's category name, for example, Sofia for a student, Tania for a teacher, Fatima for a future teacher, Uliana for a university teacher, and Henrique for a health professional.

In addition to these five groups of participants involved in the $\mathrm{CoC}$ process, members of the school community and students' relatives or friends that had had cancer participated indirectly in this study, as students interviewed them.

The Ethics Committee of UNIJUÍ approved the research project (Ref. 2.260.474). All subjects, including students' parents involved in this work, signed the Informed Consent.

\section{DESCRIPTION OF THE SITUATION OF STUDY DEVELOPED IN CO-CREATION}

As referred to above, the $\mathrm{SoS}$ consists of four stages. In the first stage, teachers $(\mathrm{T})$, future teachers $(\mathrm{F})$, and students $(\mathrm{S})$ discussed several possibilities of developing a SoS. Working with the cancer issue, on a study named "Knowing cancer: a way to life" was decided consensually. Students' interaction with teachers from the very beginning of a decision about the topic to be worked out is a matter of major relevance in the $\mathrm{CoC}$ process (Dean, Griffin and Kulczynski, 2016; Witell et al., 2011). In the second stage of SoS, the T, F, U, and $\mathrm{H}$ groups identified the curriculum topics that could be linked to the theme "Knowing cancer: a way to life". This activity contributed to the transposition of the envisaged formal curriculum to the actual classroom curriculum. 
This informed part of the first "reflecting and planning" phase of the spiral of self-reflexive cycles in participatory action research (Carr and Kemmis, 1988; Kemmis and Wilkinson, 2012) runs in three main phases: "reflecting and planning", "acting and observing", and "analyzing and reflecting" (Figure 1).

\section{Reflecting \& \\ Planning}
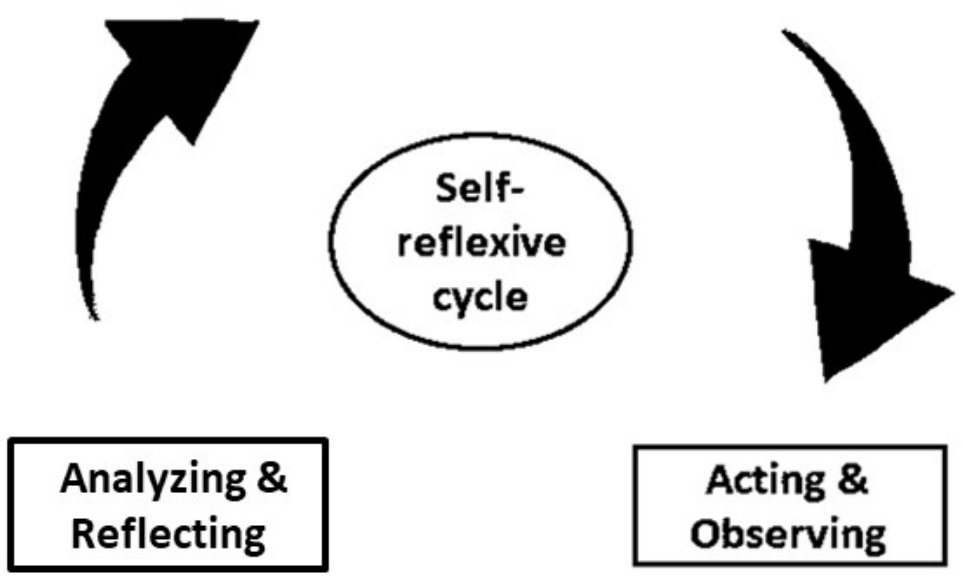

\section{Acting \& Observing}

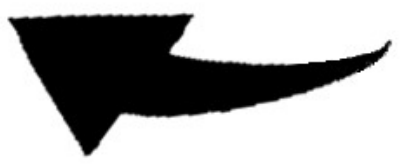

Figure 1-Spiral of self-reflexive cycles: "reflecting and planning", "acting and observing" and "analyzing and reflecting".

After the "reflecting and planning" phase, the S, T, and F groups participated in "acting and observing" in the classroom and, subsequently T, F, U, and H groups performed the "analyzing and reflecting" action, with a renewed look at school practices, and so proceed to the next spiral stage "reflecting and planning"(Figure 1). This spiral is a dynamic process and, therefore, there was no rigid sequence of steps to be followed. In addition, there was always a reflection in the planning process as well as during and after the classroom activities, in collaborative research work, as discussed by Miskovic and Hoop (2006). T, F, and U groups met weekly for two hours to analyze the classroom activities carried out in the previous week and discuss the next school activities. When required, group $\mathrm{H}$ (health professionals) was invited to collaborate with T, F, and $U$ groups to clarify and deeper understand cancer issues. This self-reflexive cycle corresponds to the SoS third stage, i.e., the implementation. 
The SoS fourth stage consisted of a final global evaluation of the whole process carried out with $\mathrm{S}, \mathrm{T}, \mathrm{F}$, and $\mathrm{U}$ groups to propose and plan a subsequent SoS developed in co-creation (see Activity 9 for details).

\section{ACTIVITIES CARRIED OUT IN THE SITUATION}

\section{OF STUDY "KNOWING CANCER: A WAY TO LIFE"}

This SoS was developed in three steps, the first concerning two activities ( 1 and 2$)$, the second, step five activities ( 3 to 7 ), and the third step with three activities (8 to 10), as briefly described below.

\section{Step A: raising the problem}

Having decided to study the topic of cancer, raising the problem intended to make students think more intensely about their knowledge on this topic. S, T, and $\mathrm{F}$ groups carried out the following two activities of this Step A:

- Activity 1: Survey of students' daily living issues. The students discussed what they knew about cancer, considering issues such as the meaning/ idea of the term cancer; acquaintance of people who had or had had cancer; factors that can cause or prevent cancer;

- Activity 2: Short interview of patients with cancer. S, T, and F groups prepared a short interview guide and students applied it to those persons of the school community and students' relatives or friends who had or had had cancer. The interview guide asked about the interviewees' profession or occupation; their lifestyle (smoking, diet, and physical activity); their age when the disease was diagnosed; the type of oncological treatment they underwent and how they responded to it; family support during the treatment process; the health plan they followed for their everyday life; their idea about the cause of the disease; and what influence the disease had on their overall life.

\section{Step B: deepening the cancer concept}

The Step B aimed to deepen the understandings about the arguments expressed by the students and to produce more complex meanings to the concept of cancer. This step included five activities (3 to 7):

- Activity 3: Visiting the "Center of High Complexity in Oncology" (Centro de Alta Complexidade em Oncologia - CACON). All S, T, F, U, and H groups participated in this activity. They all met at the CACON center for 4 hours. Local health professionals (doctors, nutritionists, pharmacists, and nurses) explained and discussed with the students scientific, technical and human aspects of the institution, specifically: forms of cancer treatment (chemotherapy, radiotherapy, brachytherapy, and medications); methods of preparation of medical products for application; the effects of treatment on patients; patients' general care; and the importance of an adequate diet. Hospital facilities (structure, equipment, and technologies) were also discussed and some areas of the hospital were visited; 
- Activity 4: Understanding the different types of cancer. Groups S, T, and $\mathrm{F}$ participated in this activity. In pairs, students did an assignment based on literature review to deepen their knowledge about types of cancer (breast, prostate, colon and rectum, lung, stomach, cervix, oral cavity, esophagus, leukemia, cutaneous melanoma, non-melanoma skin, among others). Their search also included: factors that can increase cancer predisposition (genetic, occupational, eating habits, smoking, alcohol, sun exposure, etc.), complications and available treatments, and types of cancer with a higher incidence in the region, in the country, and the world. $\mathrm{T}$ and $\mathrm{F}$ facilitated the students' work who, in pairs, made their own written recordings;

- Activity 5: Debating the literature review outcomes. The students' literature review outcomes were the matter of classroom debate with the same $\mathrm{S}, \mathrm{T}$, and $\mathrm{F}$ groups as in Activity 4. The debate was audio-recorded and, together with students' recordings, were used for subsequent discursive textual analysis (Moraes and Galiazzi, 2011);

- Activity 6: Identifying tumors in human anatomical pieces. The students had the opportunity to manipulate, with gloves, human anatomical pieces of lung and other tissues with neoplasia and equivalent normal pieces provided by the university lecturers ( $U$ group). This activity of comparing tumor tissues with normal ones generated many questions from students. Groups S, T, F, and U participated in it;

- Activity 7: Visiting the University microscopy laboratory. Participants of all groups $\mathrm{S}, \mathrm{T}, \mathrm{F}, \mathrm{U}$, and $\mathrm{H}$ visited the microscopy laboratory to observe and identify neoplastic and normal tissues by optical microscopy.

\section{Step C: structuring learning}

This Step C aimed to systematize the knowledge built in the previous steps, through the interaction between all participants, by retaking initial discussions but developing them at a higher level of understanding, in the light of the acquired knowledge during the learning processes. This step included the following three activities (8 to 10):

- Activity 8: Elaboration of the SoS Conceptual Map. From the transcripts of audio records of the classroom activities and teachers' meetings, key concepts could be identified and organized in the form of a conceptual map, by using the Cmaptools program (Cañas et al., 2005; Moreira and Buchweitz, 1993; Souza and Boruchovitch, 2010). The T, F, and U groups participated in this activity, and the results are shown below;

- Activity 9: Assessment of the acquired knowledge and the SoS process. The most involved participants in the SoS (S, T, and F groups) wrote a short text referring to the topic and concepts addressed and to the evaluation of the whole SoS process. A meeting with the T, F, and $\mathrm{U}$ groups was held to make the final analysis of the SoS progress to decide whether to continue it or to conclude it, as well as to make suggestions for improving future $\mathrm{SoS}$ in this topic; 
- Activity 10: Whole school community seminar. A seminar on risk factors and cancer prevention was addressed to the vast whole school community: parents, family, community members who had or had had cancer and the general local community. All S, T, F, U, and H groups participated in this event. This moment of interaction with the community was important for students' systematization and consolidation of their knowledge and attitudes about the topic.

\section{RESULTS AND DISCUSSION}

Students had a central role in selecting the topic "'Knowing cancer: a way to life" and were very active in this decision. The fact that students had a major role from the very beginning of the SoS, clearly showed that the SoS learning process was initiated in the CoC process (Ribes-Giner, Perello-Marín and Díaz, 2016; Witell et al., 2011).

Significant moments of illustrative examples of the SoS implemented with relevant $\mathrm{CoC}$ process were selected to be presented and discussed herein. Such findings resulted from the analysis of the transcribed audio recordings and students' texts.

After students had chosen the topic of the SoS, the process of self-reflexive cycles was initiated - "reflecting and planning", "acting and observing", and "analyzing and reflecting" (Figure 1). As said above, it is a dynamic process with no rigid sequence of steps (Miskovic and Hoop, 2006), but here it is presented in a logical and progressive way.

\section{REFLECTING AND PLANNING}

The beginning of the "reflecting and planning" phase started with a debate between university teachers $(\mathrm{U})$, school teachers $(\mathrm{T})$, and future teachers $(\mathrm{F})$ to get a clear and common idea about the $\mathrm{SoS}$ and $\mathrm{CoC}$ concepts. The university teacher (Uliana) took stock at a given moment of the conversation and clarified the SoS common idea regarding the specific topic "Knowing cancer: a way to life":

- So, the idea of SoS, for those who have never worked with it, is what the words mean: situation of study. Therefore, we will work on those concepts that are necessary in each curricular component, but not separately, to understand the overall situation of study. In the case of cancer, we work the concepts, but not because they are in a list of concepts to be memorized without having any meaning; on the contrary, they will get a meaning as they are studied. So that's one of the main goals for studying the topic in the context of a situation of study. In fact, the concepts we work on are from everyday situations and problems. Students will try to understand the SoS through scientific concepts [...] the cell biology and cell multiplication will be studied, or the chemistry will not fail to work on the concepts of atoms, chemical bonds [...] the substances 
used in cancer treatment, the interaction of atoms, particles; physics will work on the issue of radiation, and how the treatment is done through radiotherapy. Then each area will reflect on the concepts necessary to understand cancer, without neglecting the specific disciplinary contents. (Uliana)

\section{ACTING AND OBSERVING}

For the "acting and observing" phase four extracts of the SoS "Knowing cancer: a way to life", which were found to be relevant to illustrate this SoS implementation with $\mathrm{CoC}$ concept implication, were selected. The selected extracts of activities report to "Step A: Raising the problem" and "Step B: Deepening the cancer concept" (see Methodology) and are as follows:

- Activity 2: Short interview of patients with cancer (Step A): extracts of interviews carried out by students with persons who have/had cancer;

- Activity 3: Visiting the CACON (Step B): one teacher and one doctor clarifying scientific and technical cancer aspects;

- Activity 5: Debate on the literature review outcomes (Step B): one teacher and two students debating the students' assignments;

- Activity 5: Debate on the literature review outcomes (Step B): two university teacher trainers and two students debating the students' assignments.

Activity 2 intended to make students aware of the human aspects related to the cancer disease. They interviewed people of their local community who had or had had cancer to know about their lifestyles and how they coped with the disease and treatment. These are some extracts from the interviewees' responses (I):

- I was afraid to die and leave my children and all the people I love. But, I learned to fight against this disease (I1);

- When I found out about the disease I went into despair and then it got worse because I didn't know what to do, whether I would continue working or not, and how I would treat it (I8);

- Firstly, the lack of information and secondly the fear (I5);

- Difficulty to talk about the disease, a certain embarrassment of saying he had cancer, because he only found out about it when he went to the hospital (I6);

- Prejudice, low self-esteem, financial difficulties, and despair (I9);

- I was 45, it was because I had smoked since I was 15 (I3);

- The most likely cause is cigarette smoking (I2);

- I had to accept that I had the disease and see that smoking was only good as far as to make me sick (I4). 
The aspects pointed out by the first five interviewees (I1, I8, I5, I6, and I9) were more related to psychological and social aspects, whereas the last three (I13, I2, and I4) were more related to biological effects of the smoking habit (or lifestyle). These few examples, along with similar answers from the other interviewees, showed the students who interviewed them and the total team involved in the SoS (S, T, F, U, and $\mathrm{H}$ groups) how important the information and empowerment of people is in order to prevent the cancer disease and/or to cope with it. In short, Activity 2 contributed to confirm the pertinence of this SoS "Knowing cancer: a way to life", which students chose. The key fact is that students were active participants in conducting the interviews, they were actively engaged not only in in-class but also in out-of-class activities, which is an important characteristic of the $\mathrm{CoC}$ process known as "students engagement" (Dean, Griffin and Kulczynski, 2016, p. 327).

The goal of Activity 3 was to provide scientific knowledge about cancer, considering several concepts worked in the curriculum. The teacher (Tania) and the doctor (Henrique) introduced the following concepts of biology and health education into the discussion:

- About $80 \%$ of cancer cases come from exogenous factors. We could avoid, for example, smoking, which is the primary factor. In this picture, you can see it prevails, here are all the villains that cause cancer. It is responsible for $90 \%$ of lung cancer cases. Alcohol, food, our food diet... we eat a lot of industrialized, canned foods, which have nitrites, smoked foods, and many preservatives, and all that interfere with cells (Tania).

- With the advances of diagnosis and treatment, $70 \%$ of the cases can be cured. How does cancer appear? We all produce new cells every day and in this process, a mutation can happen and be accelerated in an aggressive way, making our organism no longer able to recognize these cells and delete them through our defense system. More cells are formed than we have the ability to eliminate, and it ends up with cells without function that will then be the cancer cells. These cells can be disseminated through the bloodstream in a process called metastasis. There are several environmental factors that, along with the genetic issue, cause the incidence of cancer in our body to occur, so, at this very moment, we are all developing potential cancer cells in our body, but fortunately, our immune system is able to recognize and eliminate them. This defensive process can be broken, allowing cancer cells to settle (Henrique).

These excerpts show various concepts that were worked out by the students in a subsequent discussion with their active participation, asking questions and giving some examples of their daily life knowledge. This activity contributed to the students' self-assertion, showing the importance of discussing these issues with young people, making them aware of health issues and promoting their competence for making informed, healthy choices and so contributing to self-care, disease prevention, and health promotion. 
Activity 5 concerned a debate between students, teachers, and future teachers after students had, in pairs, made an assignment based on a literature review about cancer types, onset, and treatments. Two excerpts are presented here: the first includes the dialogue between one teacher (Teresa) and one student (Samuel) who showed an effective involvement in the discussions that can potentialize cancer prevention and health promotion:

- Cancer is a disease in which the cells grow and multiply in a disorderly manner, damaging the functioning of tissues and organs [...] as I explained before, how cancer forms in our body. So the basic unit of all living beings is the cell $[\ldots]$ to reach these stages of forming the skin, forming the organs, they must divide several times to form these organs $[. .$.$] there may be several errors in the$ migration of these chromosomes, and these errors occur due to various factors, both external and internal [...] when errors occur the cell will begin to divide in a disorderly manner [...] The HPV virus, the papillomavirus, causes what type of cancer? (Teresa);

- Uterine cancer (Samuel);

- That's right! Uterine cancer, so what do girls have to do? And the boys? (Teresa);

- Use a condom (Samuel);

- Use a condom, and what else? Undergo preventive exams at least once a year. Because if the virus is detected, the doctor will already perform a treatment to combat this virus; if it is not treated, it starts to multiply and can form cancer (Teresa).

The second extract of the debate about students' assignments included three students (Salete, Silvia, and Sonia) and two university teacher trainers (Udela and Uliana) where the interdisciplinary work contributed to potentialize the problematization and to instigate the search for further search, such as in the case of women with breast cancer:

- Our work is on liver cancer. The liver is one of the largest organs in our body and its function is essential for the absorption of nutrients from the blood. It is one of the organs most attacked by metastases, which is a process characterized by the multiplication of cancer cells, in the tissues, continuously. Liver cancer is the eighth most common in the world; in turn, about $4 \%$ of cancer deaths in Brazil is due to liver cancer. It has several factors that originate, the main ones are: chronic infection, liver cirrhosis due to excessive alcohol use (Salete);

- There are several types of cancer and many can be avoided or developed by poor diet and some bad addictions like alcohol and tobacco. People are becoming aware of the idea of prevention, there is the female cancer league that helps those 
who have cancer and who are less wealthy. To help these people taking care of themselves is very important, because it preserves their life (Silvia);

- I did a chemistry work on smoking, I also said that smoking causes breast and uterine cancer (Sonia);

- Breast, uterus, liver, intestine, stomach, esophagus, oral cavity, lung, bones, I don't remember a single organ that is not associated with cancer (Udela);

- And a woman with breast cancer can breastfeed? (Silvia);

- At first she can, but if it is too advance, she won't be able to because she has other types of problems: swollen, sore breast. I've never read anything about it (Udela);

- Does it contaminate the milk? (Salete);

- Cancer produces a huge amount of defective cells, then let's say that the child will ingest these cells, they will not absorb them because it is transformed in the digestive system. It is not because they ingest a defective cell that their cells will be defective as well. I think it would be different if you think of contamination by a dangerous chemical substance you absorb. But the defect in the cell happened in the other person, the child will not absorb the cell defect. It can be passed on genetically, but that is a matter of inheriting the gene (Uliana).

Both excerpts of Activity 5 are just examples of this rich debate after the students' literature review and the previous activities they had carried out. Strong interactions between students, school teachers, future teachers, and university teachers occurred in the debate, denoting another important characteristic of the $\mathrm{CoC}$ process, the "students connectedness" which is related to the interactions students develop with others (peers, teachers, and others) showing "positive feelings of association and belonging" as referred by Dean, Griffin and Kulczynski (2016, p. 327). Indeed, "learning can be productive when students connect with the learning process and both students and practice teachers develop a relationship which enables them to work towards their learning outcomes" (Howie and Macsporran, 2010, p. 42).

\section{ANALYZING AND REFLECTING}

For this third phase of the spiral of self-reflexive cycles, "Analyzing and reflecting", extracts of two activities (8 and 10) of the "Step C: Structuring the learning" are presented:

- Activity 8: Elaboration of the SoS conceptual map (Step C): presenting the SoS conceptual map;

- Activity 9: Assessment of the acquired knowledge and the SoS process (Step C): one school teacher and one university teacher trainer analyzing what was done and making suggestions for improving the subsequent self-reflexive cycle; 
Reflective practice requires the use of "reflective diaries, reflective discussions, written work and practice itself", facilitating the breadth and depth of reflection about the practice (Gee, 2005, p. 87). In Activity 8, key concepts obtained from the transcripts of audio records of the classroom activities and of teachers' meetings were organized in the form of a conceptual map, by the Cmaptools program (Cañas et al., 2005; Moreira and Buchweitz,1993; Souza and Boruchovitch, 2010). The conceptual map is shown in Figure 2 where the multidisciplinary aspects are evident. Three groups are visible: risk factors (radiation, heredity, etc.), treatment (radiology, chemotherapy), and concepts (physics, biology, chemistry, etc.). It was clear that the SoS "Knowing cancer: a way to life" was treated in a multidisciplinary way.

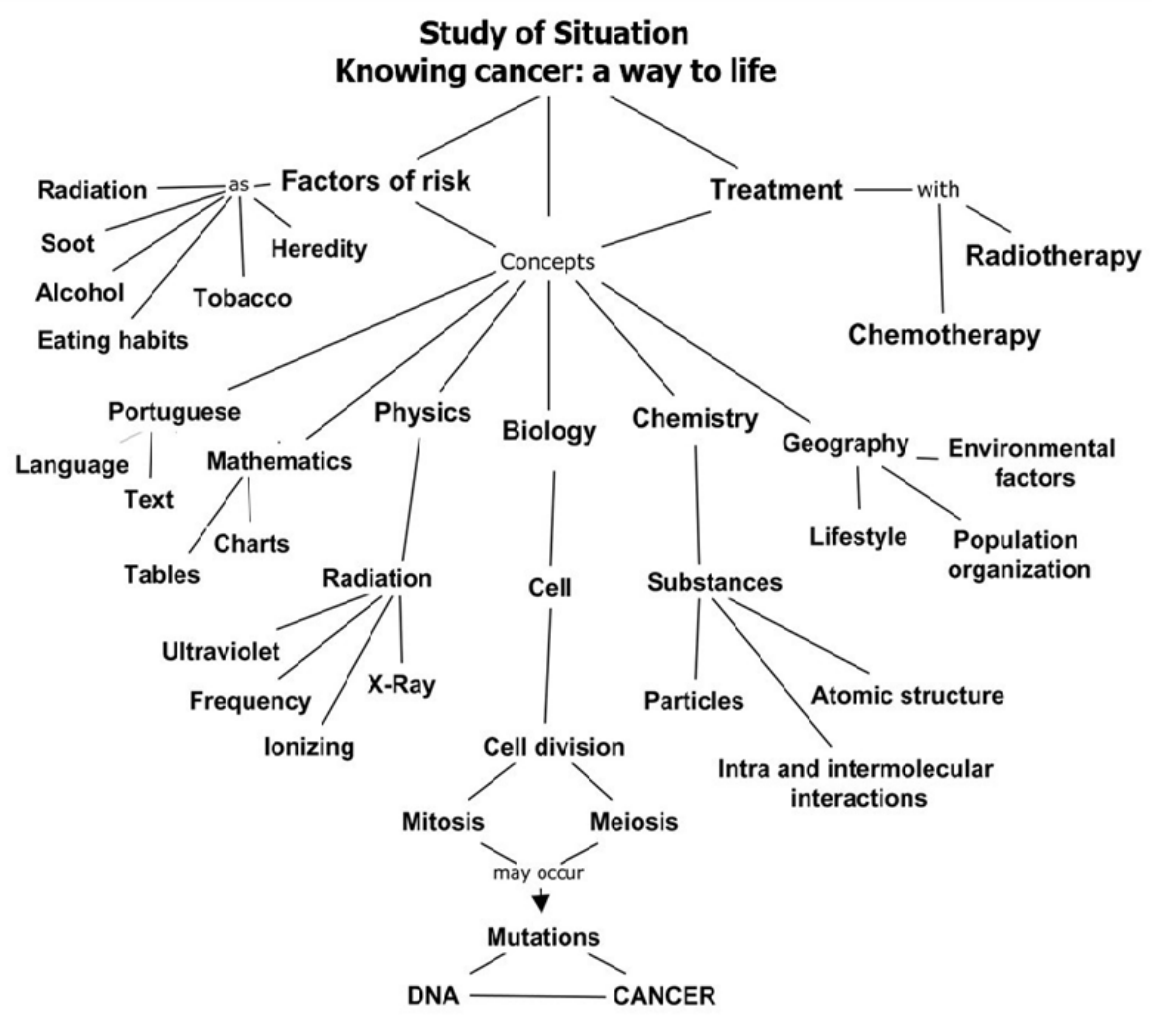

Figure 2 - Conceptual map of the SoS “Knowing cancer: a way to life”.

Activity 9 intended to make the most involved participants (S, T, F, and $\mathrm{U}$ groups) reflect on the whole process of $\mathrm{SoS}$ implementation and express the issues that might be improved in the subsequent self-reflexive cycle. After analyzing all the assignments, $\mathrm{T}, \mathrm{F}$, and $\mathrm{U}$ groups met to decide whether this $\mathrm{SoS}$ cycle should be concluded or go further on with any subsequent activity. The excerpt below refers to the dialogue between a teacher (Thalia) and a university teacher trainer (Uliana): 
- The specific purpose of our meeting today is to see how our SoS is coming along and how we are going to continue, if needed. What we have yet to do, I mean, whether we are concluding it now or not. Because we already have interdisciplinary works (Thalia).

- They could organize posters... each group could select what they've searched most. What if we have space, several spaces to expose these posters... and each group is next to their posters, so people (parents and community) can visit these places, as it happens in science fairs. It really would be an effort of the systematization of their work (Uliana).

The students' poster exhibition was the last activity (Activity 10) that showed to the local community (parents, family, interviewed persons having or having had cancer, and the general local community) the work they developed in this SoS. All $\mathrm{S}, \mathrm{T}, \mathrm{F}, \mathrm{U}$, and $\mathrm{H}$ groups participated in this school event. This was a very gratifying initiative that made students very proud of their work, which involved the local community and so leading to a very "significant learning experience" as it resulted "in something that is truly significant in terms of the students' lives" (Fink, 2003, p. 6). In this study, students were very active in the learning process and their voices were heard and taken into account by the whole group. This contrasts with many usual learning situations where students report that they are rarely asked for their opinions (Chalmers and Meldrum, 2019).

\section{CONCLUSIONS AND FINAL REMARKS}

In this study, the SoS process developed within the co-creation framework as students were active participants engaged in interactive relationships with teachers and other professionals to get what they want to learn. Indeed, the important features of the SoS were achieved in this study:

- it was developed in a real socio-environmental complex situation;

- activities were planned, implemented, and analyzed with several groups of participants (S, T, F, U, and $\mathrm{H}$ );

- multidisciplinary aspects were treated along the process;

- the process led to a significant learning experience.

Furthermore, the four main characteristics of educational $\mathrm{CoC}$ could be identified in this study:

- students participated with other groups of participants (teachers, future teachers, university teacher trainers, and health professionals) in defining the learning process;

- students participated from the very beginning of the SoS by playing an active role in the selection of the topic;

- students were active participants in making the interviews, so that they were strongly engaged not only in in-class but also in out-of-class ac- 
tivities (interviewing people, visiting $\mathrm{CACON}$ ), which demonstrated students' engagement;

- students developed interactions with others (peers, teachers, and others) showing feelings of association and belonging, which demonstrated students' connectedness.

In short, this study on a topic of health education demonstrated that the $\mathrm{SoS}$ implemented in a $\mathrm{CoC}$ process can be very efficient for students to develop significant learning, particularly when complex local socio-environmental topics are the matter of the study.

\section{ACKNOWLEDGMENTS}

This work had the Portuguese National Funds through the FCT (Foundation for Science and Technology) within the framework of the Research Center for Child Studies (CIEC) of the University of Minho, the project under reference UIDB/00317/2020.

\section{REFERENCES}

ALVES, H.; FERNANDES, C.; RAPOSO, M. Value co-creation: Concept and contexts of application and study. Journal of Business Research, v. 69, n. 5, p. 16261633, 2016. https://doi.org/10.1016/j.jbusres.2015.10.029

BARAM-TSABARI, A.; YARDEN, A. Identifying meta-clusters of students' interest in science and their change with age. Journal of Research in Science Teaching, v. 46, n. 9, p. 999-1022, 2009. https://doi.org/10.1002/tea.20294

BHARTI, K.; AGRAWAL, R.; SHARMA, V. Literature review and proposed conceptual framework. International Journal of Market Research, v. 57, n. 4, p. 571604, 2015. https://doi.org/10.2501\%2FIJMR-2015-000

BOER, J. D.; NIEBOER, A. P.; CRAMM, J. M. A cross-sectional study investigating patient-centred care, co-creation of care, well-being and job satisfaction among nurses. Journal of Nursing Management, v. 25, n. 7, p. 577-584, 2017. https://doi.org/10.1111/ jonm.12496

BOFF, E. T. O.; DEL PINO, J. C. Processo interativo de formação docente: uma perspectiva emancipatória na constituição do currículo escolar [Interactive process of teacher training: an emancipatory perspective on the constitution of the school curriculum]. Curitiba: Appris, 2018.

BOFF, E. T. O.; ROSIN, C. K.; PINTO, J. C. Situação de estudo: aproximações com as orientações curriculares nacionais e o livro didático [Situations of Study: Approaches to the National Curriculum Guidelines and the textbook]. Contexto e Educação, v. 27, n. 87, p. 166-185, 2012. https://doi.org/10.21527/2179-1309.2012.87.166-185

BRASIL. Secretaria de Educação Fundamental. Parâmetros Curriculares Nacionais: ciências naturais [National Curricular Parameters: natural sciences]. Brasil: Secretaria 
de Educação Fundamental, 1997. Available at: http://portal.mec.gov.br/seb/arquivos/ pdf/livro04.pdf. Accessed on: Apr 10, 2018.

BRASIL. Secretaria de Educação Fundamental. Parâmetros Curriculares Nacionais: terceiro e quarto ciclos do ensino fundamental - Ciências Naturais [National Curricular Parameters: third and fourth cycles of fundamental education - Natural Sciences]. Brasil: Secretaria de Educação Fundamental, 1998. Available at: http://portal.mec.gov.br/seb/ arquivos/pdf/ciencias.pdf. Accessed on: Feb. 4, 2020.

BUSCH, V.; DE LEEUW,J. R.J.; SCHRIJVERS, A.J.P. Study protocol-an exploratory trial on health promoting schools at Dutch secondary schools. International Journal of Integrated Care, v. 12, n. 5, p. 1-9, 2012. http://doi.org/10.5334/ijic.821

CAMPOS, A. C. et al. Co-creation of tourist experiences: a literature review. Current Issues in Tourism, v. 21, n. 4, p. 369-400, mar. 2018. https://doi.org/10.1080/136835 00.2015.1081158

CAÑAS, A. J. et al. Concept maps: integrating knowledge and information visualization. In: TERGAN, S.-O.; KELLER, T. (Ed.). Knowledge and information visualization: searching for synergies. Berlin, Heidelberg: Springer Berlin Heidelberg, 2005. p. 205-219.

CANOY, M. et al. Investing in youth: from childhood to adulthood. Horizons Stratégiques, v. 2, n. 4, p. 91-110, 2007.

CARR, W.; KEMMIS, S. Teoría crítica de la enseñanza: la investigación-acción en la formación del profesorado [Critical theory of teaching: the action research in teacher training]. Madrid: Martínez Roca, 1988.

CARVALHO, G. S.; BERGER, D. School health education nowadays: challenges and trends. In:JORDE, D.; DILLON, J. (Ed.). Science education research and practice in Europe: retrospective and prospective. Rotterdam: Sense Publishers, 2012. p. 309-340. CENTEIO, E. E. et al. Building healthy communities: A comprehensive school health program to prevent obesity in elementary schools. Preventive Medicine, v.111, p. 210215, 2018. https://doi.org/10.1016/j.ypmed.2018.03.005

CHALMERS, L.; MELDRUM, A. Simulation based learning in practice with interprofessional students: organic disruptive simulation and golden teachable moments. Journal of Practice Teaching and Learning, v. 16, n. 1-2, p. 110-117, 2019. https:// doi.org/10.1921/jpts.v16i1.1225

CRUMLY, C. et al.Pedagogies for student-centered learning: online and on-ground. [S.1.]: Fortress Press, 2014.

DEAN, A.M.; GRIFFIN, M.; KULCZYNSKI, A. Applying service logic to education: the co-creation experience and value outcomes. Procedia - Social and Behavioral Sciences, v. 224, p. 325-331, 2016. https://doi.org/10.1016/j.sbspro.2016.05.383

DONOVAN, B. M. Learned inequality: Racial labels in the biology curriculum can affect the development of racial prejudice. Journal of Research in Science Teaching, v. 54, n. 3, p. 379-411, 2017. https://doi.org/10.1002/tea.21370

FINK, L. D. Creating significant learning experiences: an integrated approach to designing college courses. San Francisco: Jossey-Bass, 2003. 
FLAY, B. R. Approaches to substance use prevention utilizing school curriculum plus social environment change. Addictive Behaviors, v. 25, n. 6, p. 861-885, 2000. https:// doi.org/10.1016/s0306-4603(00)00130-1

FLAY, B. R. Positive youth development requires comprehensive health promotion programs. American Journal of Health Behavior, v. 26, n. 6, p. 407-424, 2002. https:// doi.org/10.5993/ajhb.26.6.2

GEE, M. Reflective practice: perceptions of social work practice teachers. Journal of Practice Teaching and Learning, v. 6, n. 1, p. 71-90, 2005.

GORDON, S. C. et al. Clarifying a vision for health literacy: a holistic school-based community approach. Holistic Nursing Practice, v. 25, n. 3, p. 120-126, 2011. https:// doi.org/10.1097/hnp.0b013e3182157c34

GREENHALGH, T. et al. Achieving research impact through co-creation in community-based health services: literature review and case study. Milbank Quarterly, v. 94, n. 2, p. 392-429, 2016. https://doi.org/10.1111/1468-0009.12197

HOWIE, J.; MACSPORRAN, J. Engaging students in practice learning through a model of group supervision. Journal of Practice Teaching and Learning, v. 10, n. 1, p. 27-44, 2010. https://doi.org/10.1921/jpts.v10i1.240

HUBLEY, J.; COPEMAN, J.; WOODALL, J. Practical health promotion. 2. ed. Cambridge: Polity Press, 2013.

ISMAIL, K. H.; BADAYAI, A. R. A.; KULASINGAM, K. R. Children development and well-being: a review of environmental stressors in children physical environment. eBangui - Journal of Social Sciences and Humanities, v. 14, n. 5, p. 1-10, 2017.

JOURDAN, D. Health education in schools: the challenge of teacher training. Saint Denis: INPES, 2011.

JOURDAN, D. et al. The future of health promotion in schools goes through the strengthening of teacher training at a global level. Promotion \& Education, v. 15, n. 3, p. 36-38, 2008. https://doi.org/10.1177/1025382308095657

KEMMIS, S.; WILKINSON, M. A pesquisa-ação participativa e o estudo da prática [Participatory action research and practice study]. In: DINIZ-PEREIRA, J. E.; ZEICHNER, K. M. (Ed.). A pesquisa na formação e no trabalho docente. 2. ed. Belo Horizonte: Autêntica, 2012. p. 31-50.

KILGOUR, L. et al. Health literacy in schools: prioritising health and well-being issues through the curriculum. Sport, Education and Society, v. 20, n. 4, p. 485-500, 2015. https://doi.org/10.1080/13573322.2013.769948

KOHLER, T. et al. Co-creation in virtual worlds: The design of the user experience. MIS Quarterly, v. 35, n. 3, p. 773-788, 2011. https://doi.org/10.2307/23042808

LEITE, C. T. et al. The school health program: teachers' perceptions. Investigación y Educación en Enfermería, v. 33, n. 2, p. 280-287, 2015. https://doi.org/10.17533/ udea.iee.v33n2a10

MARMOTT, M. Fair society, healthy lives: The Marmot review. London: UCL - Institute of Health Equity, 2010. Available at: https://www.local.gov.uk/marmotreview-report-fair-society-healthy-lives. Accessed on: Feb. 4, 2021. 
MARTIN, A. J. et al. The role of a museum-based science education program in promoting content knowledge and science motivation. Journal of Research in Science Teaching, v. 53, n. 9, p. 1364-1384, 2016. https://doi.org/10.1002/tea.21332

MIRANDA, M. G.; RESENDE, A. C. A. Sobre a pesquisa-ação na educação e as armadilhas do praticismo. Revista Brasileira de Educação, v. 11, n. 33, p. 511-518, 2006. https://doi.org/10.1590/S1413-24782006000300011

MISKOVIC, M.; HOOP, K. Action research meets critical pedagogy: Theory, practice, and reflection. Qualitative Inquiry, v. 12, n. 2, p. 269-291, 2006. https://doi. org/10.1177\%2F1077800405284367

MORAES, R.; GALIAZZI, M. C. Análise textual discursiva [Discursive textual analysis]. 2. ed. Ijuí: Editora Unijuí, 2011.

MOREIRA, M. A.; BUCHWEITZ, B. Novas estratégias de ensino e aprendizagem: os mapas conceptuais e o Vê epistemológico [New teaching and learning strategies: conceptual maps and epistemological Vee]. Lisboa: Plátano, 1993.

MORÉS, F. B.; SILVEIRA, E. Unveiling the notion of health in a group of children included in health promotion activities. Saúde em Debate, v. 37, n. 97, p. 241-250, 2013.

OPPERMANN, E. et al. Uncovering young children's motivational beliefs about learning science.Journal of Research in Science Teaching, v. 55, n. 3, p. 399-421, 2018. https://doi.org/10.1002/tea.21424

PINAR, M. et al. Utilizing the brand ecosystem framework in designing branding strategies for higher education. International Journal of Educational Management, v. 25, n. 7, p. 724-739, 2011. https://doi.org/10.1108/09513541111172126

POMMIER, J. et al. School health promotion: Organization of services and roles of health professionals in seven European countries. European Journal of Public Health, v. 20, n. 2, p. 182-188, 2010. https://doi.org/10.1093/eurpub/ckp117

PRAHALAD, C. K.; RAMASWAMY, V. Co-opting customer competence. Harvard Business Review, v. 78, n. 1, p. 79-90, 2000.

PRAHALAD, C. K.; RAMASWAMY, V. Co-creating unique value with customers. Strategy \& Leadership, v. 32, n. 3, p. 4-9, 2004. https://doi. org/10.1108/10878570410699249

RAMÍREZ, M.-S.; GARCÍA-PEÑALVO, F.-J. Co-creation and open innovation: Systematic literature review. Comunicar, v. 26, n. 54, p. 9-18, 2018. https://doi. org/10.3916/C54-2018-01

RIBEIRO, H. C. M.; TAVARES, V. C. M.; COSTA, B. K. Cocriação de valor: Uma Bibliometria de 2000 a 2014 [Co-creation of value: a bibliometry from 2000 to 2014]. Revista Eletrônica de Estratégia \& Negócios, v. 9, n. 1, p.118-151, 2016. http://dx.doi. org/10.19177/reen.v9e12016118-151

RIBES-GINER, G.; PERELLO-MARÍN, M. R.; DÍAZ, O. P. Co-creation Impacts on Student Behavior. Procedia - Social and Behavioral Sciences, v. 228, p. 72-77, 2016. https://doi.org/10.1016/j.sbspro.2016.07.011 
ROBERTS, D. L.; DARLER, W. Consumer co-creation: An opportunity to humanise the new product development process. International Journal of Market Research, v. 59, n. 1, p. 13-33, 2017. https://doi.org/10.2501\%2FIJMR-2017-003

SANTOS, W. L. P. Educação científica na perspectiva de letramento como prática social: funções, princípios e desafios. Revista Brasileira de Educação, v. 12, n. 36, p. 474-550, 2007. https://doi.org/10.1590/S1413-24782007000300007

SOUZA, N. A.; BORUCHOVITCH, E. Mapas conceituais: estratégia de ensino/ aprendizagem e ferramenta avaliativa [Conceptual maps: teaching and learning strategies and an evaluative tool]. Educação em Revista, v. 26, n. 3, p. 195-218, 2010. https://doi.org/10.1590/S0102-46982010000300010

THIESEN, J. S. A interdisciplinaridade como um movimento articulador no processo ensino-aprendizagem. Revista Brasileira de Educação, v. 13, n. 39, p. 545-554, 2008. https://doi.org/10.1590/S1413-24782008000300010

VESNA, R.-L.; NEMANJA, L. Application of marketing mix concept in student recruitment strategies: Evidence from university of Novi Sad, Serbia. Megatrend Revija, v. 13, n. 3, p. 183-202, 2016. https://doi.org/10.5937/MegRev1603183R

VOORBERG,W.H.; BEKKERS, V.J.J. M.;TUMMERS, L. G. A systematic review of co-creation and co-production: embarking on the social innovation journey. Public Management Review, v. 17, n. 9, p. 1333-1357, 2015. https://doi.org/10.1080/1471 9037.2014.930505

WITELL, L. et al. Idea generation: customer co-creation versus traditional market research techniques. Journal of Service Management, v. 22, n. 2, p. 140-159, 2011. https://doi.org/10.1108/09564231111124190

WORLD HEALTH ORGANIZATION (WHO). Health 2020: a European policy framework supporting action across government and society for health and well-being. Copenhagen: WHO, 2013. Available at: http://www.euro.who.int/_data/assets/ pdf_file/0006/199536/Health2020-Short.pdf?ua=1. Accessed on: Feb 2, 2018.

\section{ABOUT THE AUTHORS}

Graça Simões de Carvalho has a doctorate in biology from the Universidade de Aveiro (Portugal). She is a professor at the Universidade do Minho (Portugal). E-mail: graca@ie.uminho.pt

Eva Teresinha De Oliveira Boff has a doctorate in education from the Universidade Federal do Rio Grande do Sul (UFRGS). She is a professor at the Universidade Regional do Noroeste do Estado do Rio Grande do Sul (UNIJUÍ). E-mail: evaboff@unijui.edu.br

Maria Cristina Pansera de Araújo has a doctorate in genetics and molecular biology from the Universidade Federal do Rio Grande do Sul (UFRGS). She is a professor at the Universidade Regional do Noroeste do Estado do Rio Grande do Sul (UNIJUÍ).

E-mail:pansera@unijui.edu.br 
Conflicts of interest: The authors certify that they have no commercial or associative interest that represents a conflict of interest in connection with the manuscript.

Funding: Foundation for Science and Technology and Research Center for Child Studies of the University of Minho, project under reference UIDB/00317/2020.

Authors' contributions: Conceptualization, Investigation, Methodology, Supervision, Validation, Visualization, Writing - Revision and Edition: Carvalho, G.S.; Boff, E.T.O., Araújo, M.C.P.; Funding Acquisition: Carvalho, G.S.; Boff, E.T.O. Project Administration: Boff, E.T.O.; Araújo, M.C.P.Formal Analysis, Data Curation, Writing - First Draft; Resources. 